\title{
Peningkatan Kualitas Limbah Buah Kopi dengan Phanerochaete chrysosporium sebagai Pakan Alternatif
}

\section{Increasing the Nutrient Quality of Coffee Seed Waste using Phanerochaete chrysosporium as Alternative Feedstuff}

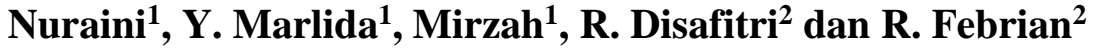 \\ ${ }^{1}$ Fakultas Peternakan Universitas Andalas \\ ${ }^{2}$ Mahasiswa Fakultas Peternakan Universitas Andalas \\ email: naninuraini63@yahoo.co.id \\ (Diterima: 21 Januari 2015; Disetujui: 10 April 2015)
}

\begin{abstract}
ABSTRAK
Limbah buah kopi bisa digunakan sebagai pakan alternatif berdasarkan potensi ketersediaannya dan kandungan nutrisinya. Penelitian ini bertujuan untuk meningkatkan kualitas nutrisi limbah buah kopi melalui fermentasi dengan Phanerochaete chrysosporium. Metode eksperimen yang digunakan adalah dengan Rancangan Acak Lengkap (RAL) pola faktorial 3 x 2 dengan 3 ulangan. Faktor pertama, dosis inokulum yaitu: 4\%, 7\% dan 10\% dari jumlah substrat. Faktor kedua, lama fermentasi: 7 hari dan 10 hari. Peubah yang diamati adalah protein kasar, serat kasar, retensi nitrogen dan kecernaan serat kasar. Hasil penelitian yang diperoleh adalah interaksi antara dosis inokulum 7\% dan lama fermentasi dengan Phanerochaete chrysosporium 10 hari dapat menurunkan serat kasar dan meningkatkan protein kasar, retensi nitrogen dan kecernaan serat kasar limbah buah kopi fermentasi. Kesimpulan penelitian ini adalah fermentasi dengan Phanerochaete chrysosporium dengan dosis inokulum 7\% dan lama fermentasi 10 hari merupakan perlakuan terbaik untuk peningkatan kualitas nutrisi dari limbah buah kopi.
\end{abstract}

Kata kunci: fermentasi, kualitas nutrisi, limbah buah kopi, Phanerochaete chrysosporium

\section{ABSTRACT}

Coffee seed waste can be used as an alternative feed based on the potential availability and nutrient content. The experiment was conducted to improve the nutrient quality of coffee seed waste $(\mathrm{CW})$ through fermentation using Phanerochaete chrysosporium. The experiment was carried out in a $3 \times 2$ factorial experiment in completely randomized design (CRD) with 3 replicates. First factor was inoculum doses of P. chrysosporium $(4,7$, and $10 \%$ from total substrate) and second factor was incubation period (7, and 10 days). Parameters measured were Crude Fiber (CF), Crude Protein (CP), Nitrogen retention and Crude fiber digestion. Result of the experiment showed the interaction between inoculum doses and incubation period, in which $P$. chrysosporium inoculum dose at $7 \%$ and incubation period for 10 days reduced $C F$ and increased $\mathrm{CP}$ content, nitrogen retention and crude fiber digestion. In conclusion, fermentation using Phanerochaete chrysosporium inoculum dose at $7 \%$ and incubation period for 10 days was the best treatment for improving CFW's nutrient quality.

Keywords: coffee seed wastes, fermentation, nutrient quality, Phanerochaete chrysosporium

\section{PENDAHULUAN}

Limbah hasil pertanian/limbah agro industri dapat dijadikan pakan alternatif dalam meningkatkan ketersediaan bahan baku penyusun ransum. Kelebihan pemanfaatan limbah sebagai pakan ternak adalah mempunyai kandungan gizi dan ketersediaan 
bahan baku penyusun ransum yang tidak bersaing dengan kebutuhan manusia dan kadang bertujuan untuk mengurangi pencemaran lingkungan. Salah satu limbah pertanian yang belum termanfaatkan secara optimal yaitu limbah/kulit buah kopi.

Tanaman kopi adalah salah satu komoditi pertanian yang mempunyai nilai ekonomis yang tinggi. Produksi kopi di Provinsi Sumatera Barat pada tahun 2010 mencapai 34.121 ton (Badan Pusat Statistik, 2011). Buah kopi biasanya diolah menjadi bubuk kopi melalui pengolahan lebih lanjut. Dalam kondisi segar buah kopi terdiri dari kulit buah $45 \%$, mucilage 10\%, kulit biji $5 \%$ dan biji kopi $40 \%$ (Murni dkk, 2008). Limbah dari pengolahan kopi yaitu kulit buah kopi yang umumnya dimanfaatkan petani sebagai pupuk dan limbah kopi juga dapat dimanfaatkan sebagai pakan ternak unggas. Menurut Nuraini (2013) limbah buah kopi mengandung protein kasar $9,31 \%$ dan serat kasar tinggi yaitu 25,61\% (lignin 21,67\% dan selulosa 20,22\%). Muryanto dkk. (2004) melaporkan bahwa pemberian 5\% kulit buah kopi dalam ransum tidak berpengaruh terhadap pertambahan bobot badan broiler. Kendala pemanfaatan limbah buah kopi sebagai pakan disebabkan oleh kualitas nutrisi yang rendah (protein rendah dan serat kasar tinggi).

Tingginya serat kasar pada limbah buah kopi menyebabkan kualitas nutrisinya rendah. Untuk meningkatkan kualitas nutrisi dari limbah buah kopi diperlukan teknologi pengolahan, salah satunya adalah teknologi fermentasi. Proses fermentasi dapat memecah komponen komplek seperti karbohidrat, protein dan lemak menjadi zat - zat yang lebih sederhana seperti glukosa, asam amino dan asam lemak sehingga mudah dicerna oleh ternak. Melalui fermentasi dengan Phanerochaete chrysosporium diharapkan kandungan serat kasar (terutama lignin dan selulosa) dari limbah buah kopi dapat berkurang.

Menurut Dhawale dan Kathrina (1993) dan Howard et al. (2003) Phanerochaete chrysosporium dapat mendegradasi lignin dan senyawa turunannya secara efektif dengan cara menghasilkan enzim peroksidase ekstraselular yang berupa lignin peroksidase (LiP) dan mangan peroksidase (MnP).

Hasil penelitian Fadilah dkk. (2008) kandungan lignin dari batang jagung dapat berkurang sebanyak $64,40 \%$ dengan bantuan enzim ligninase dan kandungan selulosa berkurang sebanyak $25,03 \%$ dengan bantuan enzim selulase yang dihasilkan Phanerochaete chrysosporium pada lama fermentasi 15 hari. Aisah (2009) menyatakan bahwa fermentasi sludge kertas dengan kapang Phanerochaete chrysosporium diperoleh aktivitas enzim LiP $0,789 \mathrm{U} / \mathrm{ml}$ dan $\mathrm{MnP} 0,062 \mathrm{U} / \mathrm{ml}$. Huang et al. (2008) melaporkan bahwa degradasi lignin jerami pada hari ke 4 setelah inkubasi sebesar 21,33\% dengan produksi LiP dan MnP dari Phanerochaete chrysosporium masing-masing sebesar 1.80 dan $4.77 \mathrm{U} / \mathrm{ml}$. Nuraini (2013) menyatakan fermentasi campuran limbah buah coklat dengan Phanerochaete chrysosporium dengan lama fermentasi 8 hari dapat menurunkan kandungan serat kasar sebanyak $32,14 \%$.

Keberhasilan dari fermentasi dipengaruhi oleh faktor-faktor yaitu: dosis inokulum, lama fermentasi, komposisi substrat dan ketebalan substrat (Nuraini, 2006). Hasil penelitian sebelumnya melaporkan bahwa komposisi substrat yaitu $80 \%$ limbah buah kopi dan 20\% ampas tahu dengan ketebalan 1 $\mathrm{cm}$ adalah komposisi terbaik untuk pertumbuhan kapang Phanerochaete crhysosporium. Pada kondisi tersebut diperoleh peningkatan protein kasar sebanyak 42,62\% (dari $13,77 \%$ menjadi 19,64\%) dan penurunan serat kasar sebanyak 30,93\% (dari $23,08 \%$ menjadi $15,94 \%$ ). Penurunan serat kasar pada penelitian ini belum optimal. Oleh karena itu perlu dipelajari dan diteliti lebih lanjut pengaruh dosis inokulum dan lama fermentasi limbah buah kopi dengan Phanerochaete crhysosporium terhadap kandungan protein kasar, serat kasar, kecernaan serat kasar dan energi metabolisme yang belum diketahui. 


\section{METODE}

Penelitian ini dilakukan dengan menggunakan metode eksperimen. Rancangan percobaan yang digunakan adalah Rancangan Acak Lengkap (RAL) pola faktorial 3 x 2 dengan 3 ulangan (Steel dan Torrie. 1991). Faktor pertama, dosis inokulum yaitu: $4 \%, 7 \%$ dan $10 \%$ dari jumlah substrat. Faktor kedua, lama fermentasi 7 dan 10 hari. Peubah yang diamati adalah : Protein Kasar (\%), Serat kasar $(\%)$, Kecernaan serat kasar (\%) dan Energi metabolisme (kkal/kg).

Pembuatan fermentasi limbah buah kopi dengan Phanerochaete chrysosporium sebagai berikut: Substrat yang digunakan yaitu Limbah buah kopi (LBK) $80 \%$ dan ampas tahu (AT) $20 \%$, lalu ditambah aquades sampai kadar air 60\%, kemudian disterilisasi dalam autoclave $\left(121^{\circ} \mathrm{C}, 15\right.$ menit) lalu dibiarkan sampai suhu turun (suhu kamar). Setelah itu substrat steril diinokulasi dengan kapang Phanerochaete chrysosporium sesuai perlakuan dari jumlah substrat, kemudian diaduk secara merata dan diratakan dengan ketebalan $1 \mathrm{~cm}$, kemudian diinkubasi dengan lama fermentasi sesuai perlakuan.

Produk fermentasi diuji kandungan protein kasar berdasarkan metode Kjehdal dan serat kasar (AOAC, 1990). Uji kualitas produk fermentasi dilakukan dengan mengukur kecernaan serat kasar dan energi metabolisme. Pengukuran kecernaan serat kasar dan kandungan energi metabolisme dilakukan uji coba ke broiler, menurut metode Sibbald (1976) yang dimodifikasi. Ternak yang digunakan untuk kecernaan serat kasar dan penentuan energi metabolisme adalah broiler strain Arbor Acres CP 707 umur 4 minggu sebanyak 21 ekor yang terdiri dari 18 ekor ayam perlakuan, 3 ekor untuk mendapatakan $\mathrm{N}$ endogenus dan 3 ekor ayam memakan produk sebelum fermentasi. Ayam terlebih dahulu di puasakan selama 24 jam, kemudian ayam perlakuan dicekok memakan produk fermentasi sesuai perlakuan sebanyak 15 gram (1\% dari bobot badan). Ekskreta ditampung selama 48 jam. Kemudian dianalisis kandungan serat kasar dengan metode AOAC
(1990) dan kandungan GE (Gross Energi) dengan Bomb calorimeter.

Retensi Nitrogen (\%) dihitung dengan menggunakan rumus:

$$
\mathrm{RN}=\frac{\mathrm{N} \text { kons }-(\mathrm{N} \text { eks }-\mathrm{N} \text { endo })}{\mathrm{N} \text { kons }}
$$

Keterangan:

N kons: Jumlah bahan kering bahan yang dikonsumsi (gram) x nitrogen (\%) bahan

N ekskreta: Jumlah bahan kering ekskreta (gram) x nitrogen (\%) ekskreta

$\mathrm{N}$ endogenous : Jumlah bahan kering ekskresi endogenus (gram) x nitrogen (\%) endogenus

Kecernaan serat kasar menggunakan rumus:

$$
\mathrm{KSK}=\frac{(\mathrm{K} \times \mathrm{SK})-(\mathrm{kx} \mathrm{sk})}{\mathrm{K} \times \mathrm{SK}} \times 100 \%
$$

Keterangan:

KSK = Kecernaan serat kasar

$\mathrm{K}=$ Jumlah konsumsi pakan (gram)

$\mathrm{k}=$ Jumlah ekskreta yang dikeluarkan (gram)

SK = Serat kasar pakan (\%)

sk $\quad=$ Serat kasar ekskreta $(\%)$

\section{HASIL DAN PEMBAHASAN}

\section{Protein Kasar}

Sebelum fermentasi kandungan protein kasarnya limbah buah kopi adalah 13,23\%, dan terjadi peningkatan setelah difermentasi dengan kapang Phanerochaete chrysosporium yang dapat dilihat pada Tabel 1. Pada Tabel 1 dapat dilihat bahwa kandungan protein kasar produk fermentasi yang tertinggi terdapat pada perlakuan dosis inokulum 7\% dan lama fermentasi 10 hari yaitu $21,86 \%$ dan pada perlakuan dosis inokulum $10 \%$ dan lama fermentasi 10 hari yaitu 22,45\%.

Tingginya protein kasar pada perlakuan dosis inokulum 7\% dan lama fermentasi 10 hari dan perlakuan dosis inokulum $10 \%$ dan lama fermentasi 10 hari berkaitan dengan banyaknya dosis inokulum yang diberikan dan panjang lama fermentasi yang dilakukan, sehingga pertumbuhan kapang terlihat subur 
Tabel 1. Protein kasar dari limbah buah kopi fermentasi dengan Phanerochaete chrysosporium $(\%)$.

\begin{tabular}{cccc}
\hline Faktor A & \multicolumn{2}{c}{ Faktor B (Lama fermentasi) } & \multirow{2}{*}{ Rata-rata } \\
\cline { 2 - 3 }$($ Dosis inokulum $)$ & B1 (7 Hari) & B2 $(10$ Hari $)$ & 16,62 \\
A1 $(4 \%)$ & $16,10^{\mathrm{c}}$ & $17,13^{\mathrm{c}}$ & 19,72 \\
A2 $(7 \%)$ & $17,58^{\mathrm{c}}$ & $21,86^{\mathrm{a}}$ & 20,83 \\
\hline A3 (10\%) & $19,20^{\mathrm{b}}$ & $22,45^{\mathrm{a}}$ & \\
\hline Rata-rata & 17,63 & 20,48 & \\
\hline
\end{tabular}

Keterangan: Superskrip huruf kecil yang berbeda menunjukkan berbeda nyata $(\mathrm{P}<0,05)$

dan merata pada substrat, akibatnya banyak sumbangan protein asal tubuh kapang. Kondisi ini menyebabkan kandungan protein kasar produk fermentasi meningkat. Kandungan zat makanan produk fermentasi menurut Nuraini (2006) dipengaruhi oleh komposisi substrat, ketebalan substrat, dosis inokulum dan lama fermentasi. Semakin banyak dosis inokulum yang dipakai dengan lama fermentasi optimum maka semakin banyak pula masa sel, sehingga kombinasi dosis inokulum dan lama fermentasi yang optimum akan meningkatkan kandungan dan kualitas zat makanan dari produk fermentasi (Howard et al., 2003). Menurut Carlile dan Watkinson (1995) peningkatan kandungan protein sesudah fermentasi dapat dikatakan sebagai proses "protein enrichment" yang berarti proses pengayaan protein bahan mikroorganisme tertentu karena proses tersebut identik dengan pembuatan single cell protein (SCP) dan pada proses ini tidak dilakukan pemisahan antara sel mikroba yang tumbuh dengan substratnya. Kapang dan khamir mengandung protein $40-60 \%$ dan bakteri mengandung protein $70-80 \%$.

Disamping itu, protein kasar yang meningkat pada perlakuan dosis inokulum $7 \%$ dan lama inkubasi 10 hari juga berasal dari sumbangan enzim yang dihasilkan karena enzim tergolong ke dalam protein. Enzim ligninase dan selulase dihasilkan oleh kapang Phanerochaete chrysosporium (Howard et al., 2003).

Limbah buah kopi yang difermentasi dengan Phanerochaete chrysosporium diperoleh kondisi optimum yang efisien yaitu dosis inokulum 7\% dan lama fermentasi 10 hari. Hal serupa juga terjadi pada limbah buah coklat yang difermentasi dengan Phanerochaete chrysosporium juga terjadi peningkatan protein selama fermentasi dan diperoleh kondisi optimum yaitu dosis inokulum 7\% dengan lama fermentasi 8 hari. (Nuraini dkk. 2012).

\section{Serat Kasar}

Kandungan serat kasar limbah buah kopi sesudah difermentasi dengan Phanerochaete chrysosporium terjadi penurunan dengan semakin banyak dosis yang diberikan dan semakin lama fermentasi dilakukan, yang dapat dilihat pada Tabel 2.

Kandungan serat kasar terendah dari limbah buah kopi fermentasi dengan Phanerochaete chrysosporium terdapat pada perlakuan dosis inokulum 10\% dengan lama fermentasi 7 hari dan dosis inokulum 7\% dengan lama fermentasi 10 hari. Semakin banyak dosis yang diberikan yaitu sampai $10 \%$ menyebabkan semakin banyak kapang yang tumbuh dan semakin panjang waktu fermentasi yang diberikan, mengakibatkan kapang Phanerochaete chrysosporium dengan enzim ligninase dan selulase yang dihasilkan semakin optimal merombak lignin dan selulosa sehingga serat kasar setelah difermentasi dengan kapang Phanerochaete chrysosporium semakin rendah. Menurut Nelson dan Suparjo (2011) penurunan serat kasar dapat terjadi karena proses dekomposisi komponen serat oleh kapang Phanerochaete chrysosporium. Kapang Phanerochaete chrysosporium mempunyai kemampuan dalam 
Tabel 2. Kandungan serat kasar limbah buah kopi fermentasi dengan Phanerochaete chrysosporium.

\begin{tabular}{cccc}
\hline Faktor A & \multicolumn{2}{c}{ Faktor B (Lama fermentasi) } & \multirow{2}{*}{ Rata-rata } \\
\cline { 2 - 3 } (Dosis inokulum) & B1 (7 Hari) & B2 $(10$ Hari $)$ & 20,32 \\
A1 $(4 \%)$ & $21,50^{\mathrm{Aa}}$ & $19,15^{\mathrm{Ba}}$ & 16,01 \\
A2 $(7 \%)$ & $17,95^{\mathrm{Ab}}$ & $14,07^{\mathrm{Bb}}$ & 15,72 \\
A3 $(10 \%)$ & $16,77^{\mathrm{Ac}}$ & $14,68^{\mathrm{Bb}}$ & \\
\hline Rata-rata & 18,74 & 15,97 &
\end{tabular}

Keterangan : Superskrip huruf besar yang berbeda pada baris yang sama dan huruf kecil yang berbeda pada kolom yang sama menunjukkan pengaruh berbeda nyata $(\mathrm{P}<0.05)$

Tabel 3. Kecernaan serat kasar limbah buah kopi yang difermentasi dengan Phanerochaete chrysosporium.

\begin{tabular}{cccc}
\hline Faktor A & \multicolumn{2}{c}{ Faktor B (Lama fermentasi) } & \multirow{2}{*}{ Rata-rata } \\
\cline { 2 - 3 }$($ Dosis inokulum) & B1 (7 Hari) & B2 $(10$ Hari $)$ & 34,96 \\
\hline A1 (4\%) & $32,65^{\mathrm{Bb}}$ & $37,27^{\mathrm{Ab}}$ & 41,59 \\
A2 (7\%) & $34,11^{\mathrm{Ba}}$ & $49,06^{\mathrm{Aa}}$ & 42,98 \\
\hline A3 (10\%) & $35,79^{\mathrm{Ba}}$ & $50,16^{\mathrm{Aa}}$ & \\
\hline Rata-rata & 34,18 & 45,50 & \\
\hline
\end{tabular}

Keterangan: Superskrip huruf kapital yang berbeda pada baris yang sama dan huruf kecil yang berbeda pada kolom yang sama menunjukkan pengaruh berbeda nyata pada taraf $(\mathrm{P}<0.05)$.

mendegradasi komponen serat karena disamping menghasilkan enzim pendegradasi lignin, kapang ini juga mampu menghasilkan enzim pendegradasi selulosa (Howard at al. 2003). Menurut Aisah (2009) fermentasi sludge kertas dengan kapang Phanerochaete chrysosporium diperoleh aktivitas enzim LiP $0.789 \mathrm{U} / \mathrm{ml}$ dan $\mathrm{MnP} 0.062 \mathrm{U} / \mathrm{ml}$. Menurut Blanchette (1995) Phanerochaete chrysosporium merupakan salah satu kapang pelapuk putih yang mampu mendegradasi lignoselulosa secara efektif.

Fermentasi dengan Phanerochaete chrysosporium pada limbah buah kopi diperoleh kondisi optimum yang efisien yaitu dosis inokulum $7 \%$ dengan lama fermentasi 10 hari, sebelumnya Nuraini dkk (2012) melaporkan bahwa serat kasar limbah buah coklat yang difermentasi dengan Phanerochaete chrysosporium juga terjadi penurunan serat kasar paling tinggi dengan dosis inokulum $10 \%$ dan lama fermentasi 8 hari.

\section{Kecernaan Serat Kasar}

Kualitas nutrisi suatu bahan pakan yang salah satunya ditunjukkan oleh kecernaan serat kasar. Kecernaan serat kasar dari limbah buah kopi setelah difermentasi dengan kapang Phanerochaete chrysosporium dapat dilihat pada Tabel 3.

Kecernaan serat kasar tertinggi dari limbah buah kopi setelah difermentasi dengan Phanerochaete chrysosporium terdapat pada dosis inokulum $7 \%$ dan lama fermentasi 10 hari yaitu $49,46 \%$ dan pada perlakuan dosis inokulum $10 \%$ dan lama fermentasi 10 hari yaitu $50,16 \%$. Kecernaan serat kasar yang tinggi berkaitan dengan kandungan serat kasar yang juga lebih rendah pada ke 2 perlakuan tersebut yaitu berturut- turut $14,07 \%$ dan $14,08 \%$.

Rendahnya kandungan serat kasar disebabkan ikatan lignoselulosa dan kandungan lignin dan selulosa yang terkandung dalam limbah buah kopi dipecah oleh enzim ligninase dan selulase yang dihasilkan kapang Phanerochaete chrysosporium sehingga lebih mudah dicerna 
Tabel 4. Retensi nitrogen limbah kulit buah kopi yang difermentasi dengan Phanerochaete chrysosporium.

\begin{tabular}{cccc}
\hline Faktor A & \multicolumn{2}{c}{ Faktor B (Lama fermentasi) } & \multirow{2}{*}{ Rata-rata } \\
\cline { 2 - 3 } (Dosis inokulum) & B1 (7 Hari) & B2 $(10$ Hari) & $51,54^{\mathrm{b}}$ \\
\hline A1 (4\%) & $45,81^{\mathrm{e}}$ & $57,28^{\mathrm{bc}}$ & $57,48^{\mathrm{a}}$ \\
A2 (7\%) & $52,55^{\mathrm{d}}$ & $62,41^{\mathrm{a}}$ & $57,35^{\mathrm{a}}$ \\
\hline A3 (10\%) & $54,33^{\text {cd }}$ & $60,38^{\mathrm{ab}}$ & \\
\hline Rata-rata & $50,89^{\mathrm{b}}$ & $60,02^{\mathrm{a}}$
\end{tabular}

Keterangan: Superskrip huruf kecil yang berbeda menunjukkan berbeda nyata $(\mathrm{P}<0,05)$

akibatnya kecernaan meningkat. Winarno dkk. (1980) menyatakan bahwa makanan yang mengalami fermentasi biasanya mempunyai nilai gizi yang lebih baik dari bahan asalnya disebabkan mikroorganisme bersifat katabolik atau memecah komponen yang komplek menjadi zat-zat yang lebih sederhana sehingga lebih mudah dicerna. Semakin rendah kandungan serat kasar dalam bahan pakan maka akan semakin tinggi kecernaan serat kasar bahan pakan tersebut.

Tingginya kecernaan serat kasar limbah buah kopi setelah difermentasi dengan kapang Phanerochaete chrysosporium menunjukan bahwa kualitas bahan tersebut lebih baik, karena proses fermentasi dapat menyebabkan perubahan sifat bahan sebagai akibat pemecahan kandungan protein, lemak dan polisakarida yang dapat dihidrolisis sehingga bahan yang dihasilkan mempunyai kecernaan yang tinggi. Wahju (1997) berpendapat bahwa serat kasar hanya sedikit yang dapat dicerna oleh hewan monogastrik dan bila serat kasar tinggi dalam ransum akan mengurangi efisiensi penggunaan zat-zat makanan lainnya, selain itu efek dari serat kasar yang tidak dapat dicerna dapat membawa zat makanan yang tercerna dari bahan lain keluar melalui feses, sehingga ternak unggas tidak berproduksi dan bertumbuh dengan sempurna. Lebih jauh dijelaskan bahwa rendahnya daya cerna serat kasar karena ayam tidak mempunyai enzim selulase dalam sistem pencernaannya.

\section{Kualitas Protein}

Kualitas protein suatu bahan pakan dapat diketahui dengan mengukur retensi nitrogen dari broiler yang mengkonsumsi pakan tersebut.
Pada Tabel 4 dapat dilihat bahwa retensi nitrogen tertinggi terdapat pada perlakuan dosis inokulum 7\% dan lama fermentasi 10 hari yaitu $62,41 \%$ dan yang terendah pada perlakuan A1B1 (dosis inokulum 4\% dan lama fermentasi 7 hari) yaitu $45,81 \%$. Tingginya retensi nitrogen pada kedua perlakuan tersebut, berkaitan dengan jumlah protein kasar yang dikonsumsi juga tinggi yaitu 4,37 g/ekor dan 4,49 g/ekor. Konsumsi protein kasar yang tinggi mengakibatkan semakin banyak protein yang dicerna sehingga banyak yang ditinggalkan dalam tubuh akibatnya retensi nitrogen yang dihasilkan meningkat (Wahju, 1997). Konsumsi protein yang tinggi berkaitan pula dengan protein kasar yang lebih tinggi. Kandungan protein kasar limbah buah kopi yang difermentasi dengan Phanerochaete chrysosporium meningkat menjadi $21,86 \%$ pada perlakuan A2B2 dan pada perlakuan A3B2 protein kasar meningkat menjadi $22,45 \%$.

Tingginya retensi nitrogen menunjukkan bahwa kualitas protein yang lebih baik pada perlakuan tersebut dibandingkan perlakuan lainnya. Wahju (1997) menyatakan bahwa retensi nitrogen dipengaruhi oleh daya cerna protein, kualitas protein dan keseimbangan konsumsi nitrogen serta energi metabolisme dalam ransum. Retensi nitrogen merupakan gambaran kualitas protein suatu bahan atau ransum.

\section{KESIMPULAN}

Fermentasi dengan Phanerochaete chrysosporium dengan dosis inokulum 7\% dan lama fermentasi 10 hari merupakan perlakuan 
terbaik untuk peningkatan kualitas nutrisi dari limbah buah kopi.

\section{DAFTAR PUSTAKA}

Aisah, A.R. 2009. Pretreatment dengan Phanerochaete chrysosporium dalam hidrolisis asam encer sludge kertas. Departement Silvikultur. Fakultas Kehutanan. Institut Pertanian Bogor.

AOAC. 1990. Official Method of Analysis. $14^{\text {th }}$ Ed. Association of the Official Analitical Chemist. Washington DC.

Badan Pusat Statistik. 2011. Statistik Perkebunan Indoneisa 2009 - 2011. Badan Pusat Statistik. Jakarta.

Blanchette R.A. 1995. Degradation of lignocelluloses complex in wood. Can. J. Bot. 73(1):999-1010.

Carlile, M.J and S.C. Watkinson. 1995. The Fungi. Academic Press Inc. London.

Dhawale, S. S. and K. Kathrina., 1993. Alternatif Methods for Production of Staining of Phanerochaete chrysosporium Bacidiospores. J. Aplied and Envonmental Microbiology, May 1993 : $1675-1677$.

Fadilah, S Distanitina, E.K. Artati, dan A. Jumari. 2008. Biodelignifikasi batang jagung dengan jamur pelapuk putih (Phanerochaeta chrysosporium). Ekuilibrium Vol. 7(1):7-11

Fardiaz, S. 1989. Fisiologi Fermentasi. PAU Pangan Gizi IPB, Bogor.

Howard, R.T., E. Abotsi,. E.L. Jansen van Rensburg, and S. Howard. 2003. Lignocellulose Biotechnology : Issue of bioconversion and enzyme production, African Journal of Biotech., 2:602-612

Huang, D.L., G.M. Zeng,. C.L Feng., S. Hu., X.Y. Jiang., L. Tang., F.F. Su., Y. Zhang., W. Zeng., H.L. Liu. 2008. Biodegradation of $\mathrm{Pb}$-contaminated lignocellulosic waste by Phanerochaete chrysosporium and the reduction of lead toxicity. Environ. Sci. Technol. 42:4946-4951.

Johjima, T., N. Itoh., M. Kabuto., F. Tokimura., T. Nakagawa., H. Wariishi., and H. Tanaka., 1999. Direct interaction of lignin and lignin peroxidase from Phanerochaete chrysosporium, Proc. Natl. Acad. Sci. USA. 96. 1989-1994

Murni, R., Suparjo, Akmal dan Ginting, D.L., 2008. Buku ajar teknologi pemanfaatan limbah untuk pakan. Laboratorium Makanan, Ternak Fakultas Peternakan Universitas Jambi.

Muryanto, U. Nuschati, D. Pramono dan T. Prasetyo. 2004. Potensi limbah kulit kopi sebagai pakan ayam. Lokakarya nasional inovasi teknologi dalam mendukung usaha ternak unggas berdayasaing. Balai Pengkajian Teknologi Pertanian Ungaran. Jawa Tengah.

Nelson dan Suparjo. 2011. Penentuan lama fermentasi kulit buah kakao dengan Phanerochaete chrysosporium: evaluasi kualitas nutrisi secara kimiawi. Agrinak. (01):1-10

Nuraini. 2006. Potensi kapang karotenogenik untuk memproduksi pakan sumber $\beta$-karoten dan pengaruhnya terhadap ayam pedaging dan petelur. Disertasi. Program Pasca Sarjana Universitas Andalas, Padang.

Nuraini, M.E. Mahata, Nirwansyah. 2012. Potensi ligninolitik dan selulolitik Phanerochaete chrysosporium dan karatenoid monakolin dari Monascus purpureus dalam meningkatkan kualitas limbah buah kakao sebagai pakan ternak. Laporan Penelitian. LPPM Universitas Andalas Padang.

Nuraini. 2013. Kondisi optimum fermentasi dengan kapang Phanerochaete crysosporium terhadap kualitas nutrisi limbah agroindustri. Laporan Penelitian. Lembaga Penelitian Universitas Andalas, Padang. 
Scott. M.L, M.C. Nesheim and R.J. Young. 1982. Nutrition of The Chicken $3^{\text {rd }} \mathrm{Ed}$. Publishing. M.C. Scoot and Associates, Ithaca, New York.

Sibbald, I. R. 1976. "The effect of level intake on metabolzable energy value measured with adult rooster". Poultry Science, (54):1990-1998.

Steel, R. G. dan J. H. Torrie. 1991. Prinsip dan Prosedur Statistika : Suatu Pendekatan
Biometrik, Ed. 2, Cetakan ke- 2, Alih Bahasa B. Sumantri. PT. Gramedia Pustaka Utama. Jakarta.

Wahju, J. 1997. Ilmu Nutrisi Unggas. Gajah Mada University Press. Yogyakarta.

Winarno, F., G.S. Fardiaz dan D. Fardiaz. 1980. Pengantar Teknologi Pangan. PT. Gramedia Jakarta. 